\author{
Álvaro DELGADO-ZAPERO ${ }^{1}$ \\ Jacek STROJNY ${ }^{2}$
}

\title{
STAKEHOLDERS MANAGEMENT IN A UNIVERSITY: ANALYSIS OF THEIR IMPORTANCE WITH AHP
}

\begin{abstract}
At present, problems appear in every decision taken by people or companies. It is because each part has its own interests, normally different than each other, and they have to take care of them over the rest to achieve a high level of success in terms of following their objective. Literature about this subject is very extensive and varied. But it seems that research is mostly focussed on social field, talking about social objectives, mission and values of companies and institutions. In case of universities, the main concern is the change of directive from creating knowledge to keeping this knowledge and earn prestige and economic compensation. This paper shows the management of a university focused on the relation with its stakeholders and how can they affect or influence in decisions, and moreover, it will be giving a critic point of view about the priorities between each one. Conclusions will be supported by an Analytic Hierarchy Process and contrasted with some experts in the field, with the objective of giving a vision of how can traditional management system of universities improve in the future and focus on its main mission as social creators of knowledge.
\end{abstract}

Keywords: Stakeholders, Management, Project, AHP, University, Decisions, Importance.

\section{INTRODUCTION}

One of the most important tasks during strategy making is the management of the relationship between the many and usually competing demands of different stakeholders in relation to their strategic goals (Ackermann \& Eden, 2011).

There is enough literature about the concept stakeholder, but not every author defines this topic in the same way. Some groups conceptualised them as "groups without whose support the organization would cease to exist" (Freeman \& Reed, Stockholders and Stakehorlders; A New Perspective on Corporate Governance., 1983). In the other hand, it is also defined as groups affected by the organizations (Bryson et al., 2002; Freeman and McVea, 2001). Also, there are opener definition like "any group or individual who can affect or is affected by the achievement of the organization's objectives" (Freeman \& McVea, 1983). Looking forward, the definition of stakeholder depends on their interests and the needs of organizations.

\footnotetext{
1 Álvaro Delgado-Zapero, student at Technical University of Valencia, Camí de Vera, s/n, 46022 València, Valencia, Hiszpania.

2 Jacek Strojny, PhD, Department of Economics, Faculty of Management, Rzeszow University of Technology, Al. Powstańców Warszawy 12, 35-959 Rzeszów; e-mail: jstrojny@prz.edu.pl (corresponding author); ORCID: 0000-0003-4632-8645.
} 
However, and focusing on the subject of this document, there is much literature with main topics related to universities. Normally, authors write about its objective about creating knowledge, how they changed since decades ago, their social mission and professional responsibility, and also, they always touch politic or economic topics.

So, it is hard to find articles that takes universities like a group of many stakeholders, where everything has to work as much harmonically as possible and how to achieve that. With this document is tried to show this not too much exploited field and also tried to answer some questions about the topic.

The good management of a University is what basically allow this institution to reach its objectives. Those objectives are in a situation of constant change due to the emergence of new competitions and new elements that collide with other traditional cultures or know-how achieved from the experience.

University as whole institution has a strong impact in terms of social and economic environment, because it can get prestige and economic remuneration from its main objective, that is the creation of knowledge and professional training. The attention at the main mission and purpose of a university exists since it is built, but not for its management model. The priority of the university changed when it started to be more important patent the knowledge of its members instead of looking for the social equality. That is why companies become an important stakeholder and they can influence decisions, because they get not very expensive skilled laborers with new ways of thinking from students and increase the prestige of universities because of their agreements.

While universities had their only mission as creator of knowledge without relationships with many stakeholders, its management model wasn't determinate. Every university was different, with its own management model based in make work its objective of creation of knowledge. Directives were mainly focussed on studies, research and teaching methods. That is why it is difficult to find researches about this field. Instead of this, nowadays, literature shows that there is a concern about management models because of fast and constant change of society, emergence of new competition, etc.

Despite of that, it seems that universities want to change or improve their management models and it can changes affect to their influences, interests and agreements. It is important to analyse the balance between that stakeholders of a university should have. At least, a university works like another organization dealing with new cultures, but it has not the same purpose and mission, characteristics and management systems. That is why this topic is treated in this paper. The main objective it to reach and show a management model of stakeholders of a university and its verification based on empirical research.

\section{MAIN CHALLENGES OF THE STAKEHOLDERS MANAGEMENT IN CONTEMPORARY PUBLIC INSTITUTIONS}

As R.E. Freeman said for first time in his tittle "Strategic Management: A Stakeholder Approach", the word Stakeholder refers to every person or entity that can affect or be affected by the activities of a company.

For the right working of every institution, the fact of having a good identification and classification of its stakeholders is crucial to make easier the process of taking decisions and avoid problems, as well as the study and determination of their needs and expectations. 
Stakeholders can be classified taking into account their interest and influence:

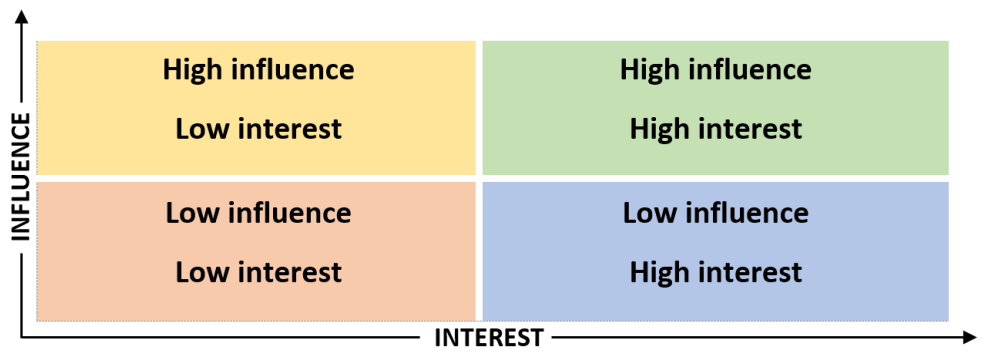

Figure 1. Influence / interest matrix.

Source: Own work based on content of Project Management master in UPV.

If every important decision taken by the university managers was taken as a project, the identification and classification of stakeholders will be carried out above all at the beginning of the project and it must remain active throughout the duration of the project. The fact of identify the stakeholders is not important only on the level of processes and project, but on strategic level as well.

In $P M B o K$, PMI defines stakeholder management in the last chapter (only from the fifth version) and is very connected to the communication management chapter in the project.
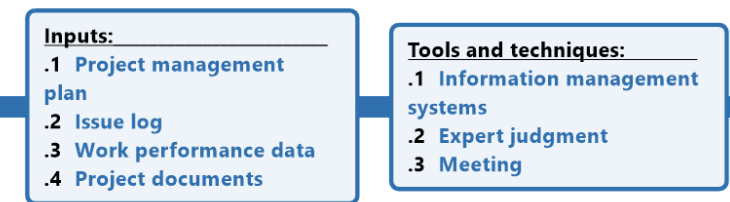

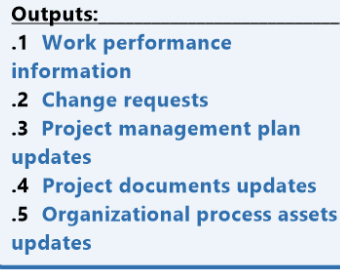

Figure 2. Inputs, tools and techniques and outputs of Control Stakeholder management process

Source: Own work based on (Pérez, 2015).

According to the $P M B o K$, stakeholders must be identified as soon as possible in the project's start process group, and then proceed to plan their management and subsequently execute the plan already in the execution process group. Moreover, there has to be a control of the stakeholders, to verify that their expectations and interests are being fulfilled, and if not, execute the necessary change requests. The process would be as the following table 1 .

1. Identify stakeholders:

- Identify all people or organizations that may impact or may be impacted by the project.

- Document the relevant information regarding their interests, how they will be involved in the project and how they can influence the outcome of the project. 
2. Plan stakeholder management:

- Make a plan that will identify how all the steps needed to execute for the correct management of the stakeholders will be carried out.

3. Manage stakeholder participation:

- Communicate with Stakeholders and work towards their needs according to the plan defined in the previous process.

- Actively manage their expectations to increase the possibility of acceptance of the project and anticipate future problems.

4. Control and monitoring:

- Constant communication with stakeholders to see their status, if they are seeing their expectations met. And if not, take the necessary actions to solve it, or even change requests.

Table 1. Steps of the Stakeholders management process

\begin{tabular}{|c|c|c|c|}
\hline Start & Planning & Execution & $\begin{array}{c}\text { Control and } \\
\text { monitoring }\end{array}$ \\
\hline $\begin{array}{c}\text { Identify } \\
\text { stakeholders }\end{array}$ & $\begin{array}{c}\text { Plan stakeholders } \\
\text { management }\end{array}$ & $\begin{array}{c}\text { Manage stakeholders } \\
\text { participation }\end{array}$ & $\begin{array}{c}\text { Control stakeholders } \\
\text { participation }\end{array}$ \\
\hline
\end{tabular}

Source: Own work based on (Pérez, 2015).

It is important to highlight that this process is very important and it has to be different for each project and process. Moreover, it has to be aligned with the objective of the manager in order to follow the corporate strategy of the company.

\section{DIMENSIONS OF THE MANAGEMENT OF THE STAKEHOLDERS}

Universities and stakeholders have a symbiotic relationship, because these relations indulge interests of each part. Universities need stakeholders to carry out part of their own services, like maintenance of facilities and infrastructures and repairs, teaching and research staff support and providing their students first opportunities for joining the labour market.

Also, this kind of relations can make universities take advantage from their competition. Better teaching guides, better infrastructures, larger research fields and tools, higher possibilities to get scholarships, etc., can make a student, employer or companies choose this universities. And the cycle starts again, more people, more knowledge, more prestige, more economic remuneration.

However, when there are many stakeholders, indulge every of them becomes a hard task. Every decision taken affects every stakeholder positively or negative. So, stakeholders are important, but relations with them are even more important. A good relation between a university and a stakeholder can make easier finding out a solution if a problem appears, and also, it can sometimes benefit to this stakeholder.

For these reasons, it is important to know that each relation with each stakeholder is different and the fact of taking care of all of them is crucial. A good way for this is to think carefully about the strategy of the university and then make a stakeholders analysis, and keep those that their mission is more or less in the same direction. It also makes easier manage them and decreases the risk of discrepancies when a decision has to be taken. 


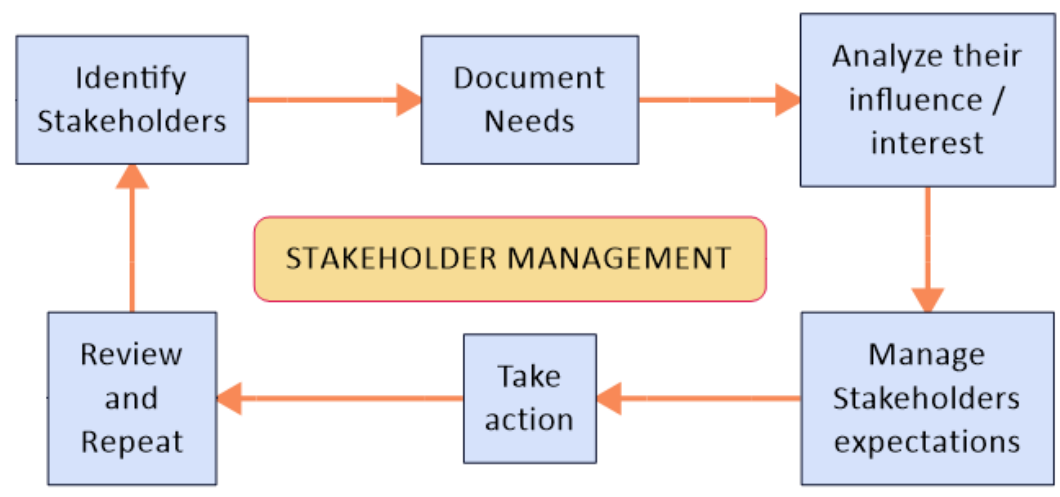

Figure 3. Flowchart of steps of Stakeholders management process

Source: Own work based on (Dwevedi, 2017).

Due to the large number of stakeholders within the management of a university, each with its own functions and interests, the university will be analysed as if it uses a management model based on public governance, an open organization in which all participate the different stakeholders providing their service and receiving an interest in return.

In the 21 st century, the State and the public administration have the great challenge of deepen democracy, since social progress in these times is determined by the way in which public institutions are linked with citizens. The new position that they occupy in that relationship must be recognized, which in turn is conditioning the consolidation of the State in its other dimensions: social, law and justice. However, it is necessary to bring institutions closer to the people and make the government's action translate into welfare for them for talking about democratization of the public sector.

Regarding the complexity of the modern state and its necessary link with citizens, it is necessary to understand that the democracy of this time, participatory and deliberative, is built on open processes, with people and regardless of any attitude of opacity. As Oszlak, (2015), states, "actually open government is not a new technological development, but a true philosophy of how to govern and what is the role that government and citizens play in public management and its results".

The objectives of open government should be focussed on the consolidation of the rule of law, the strengthening of democracy and the full recognition of the position of citizens in their relationship with the public administration, as Naser, Ramírez-Alujas \& Rosales, (2017), states. They should also focus on achieving safe cities. Moreover, this tool should facilitate public management focused on citizens and institutions closer to people. It is clear that the functioning of the government has to constantly improve, the management instruments have to contribute to good governance, good administration and democratic governance.

Villoria, (2012), rightly affirms that at least four groups of ideas can be distinguished in open governments: i) welfare promoting government through regulatory capacity; ii) transparent government that is accountable; iii) government participatory and civic promoter, and iv) efficient government, collaborator and knowledge generator. 
It is known that the efficiency of the public service, from its new conception, it is sized according to the development of societies, but also of what has been called social citizenship (Oszlak, 2015). This forces governments to rethink and redesign to reduce levels of tension that exist in that sense, and focus their structures on transparency, citizen participation, collaboration and information technology.

\section{AHP AS A METHOD FOR SUPPORTING THE ANALYSIS OF THE IMPORTANCE OF STAKEHOLDERS MANAGEMENT}

Find out which stakeholder is more important in different situations is a hard task. That is why it is very important this process and because of the choice, problems can appear or can be avoided. Even more when decisions have to be taken by not many people, without enough information and a lot of alternatives with qualitative aspects. That is why to make this process easier, there are numerous methods for taking decisions.

In this paper, the one that is going to be used is the Analytic Hierarchy Process, or AHP. This method is one of the most used methods to take decisions and it was developed by Thomas L. Saaty in the 70's to help to solve some determinated problems to Defense Department of the USA. The advantages of this method are:

- Facilitates reflection.

- Consider all the alternatives.

- Help structure the reasoning.

- Check the consistency.

- Allows to achieve an objective and reliable result.

In short, experts determines their relative preference of one concept over another helped by pairwise comparison matrixes, and it also indicates the intensity of preference according to the scale.

Hierarchy:

AHP is a multicriteria decision method that helps to select between different alternatives based on selection criteria or variables, usually hierarchized, and usually in conflict with each other. The hierarchical structure from top to bottom would be: final objective, criteria and sub-criteria (maybe) and for last the alternatives. One of the crucial aspects of the method is to choose the selection criteria and subcriteria well, define them properly and that they are mutually exclusive.

\section{Paired comparisons:}

The working of method is simple. It is about making paired comparisons following the fundamental scale, in each of the hierarchical levels. The Saaty Fundamental Scale is used to perform the paired comparison. This is one of the keys to the success of this method, because this scale allows us to transform qualitative aspects into quantitative aspects. It facilitates the comparison between the different alternatives and giving rise to more objective and reliable results. Another of the strengths of the method is to assess the consistency of experts' decisions to validate it as the best option.

In this case, data is going to be given from more than one expert. So, as Saaty states, final results will be the geometric mean of the results of each expert. The preferences of each expert will be known because of they have to fill up a questionnaire with the pairwise comparisons, and then, results will be calculated by SuperDecisions software. 


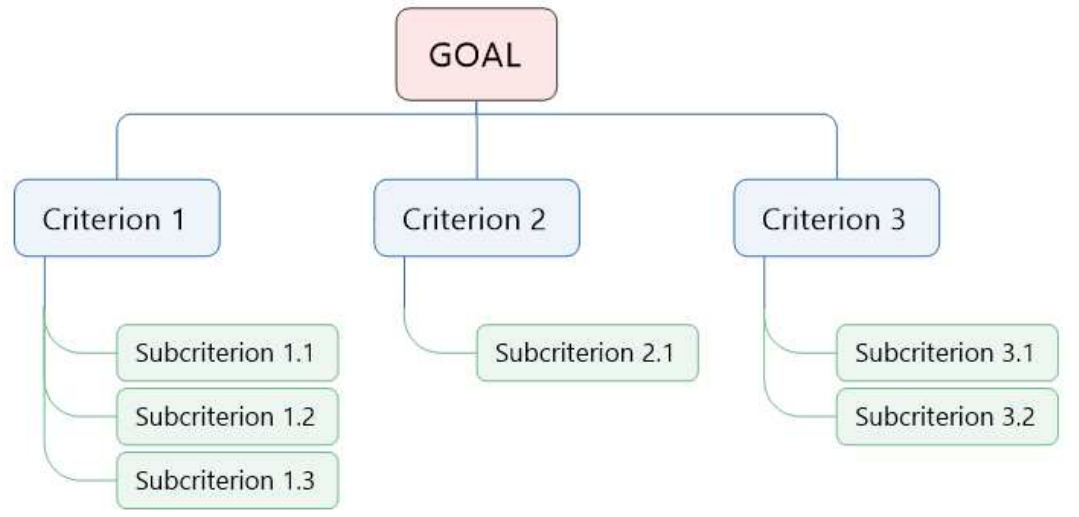

Figure 4. Multicriteria method structure

Source: Own work based on (Saaty, 1980).

Table 2. Coefficients for the intensity of importance in AHP

\begin{tabular}{|c|l|l|}
\hline $\begin{array}{c}\text { Intensity of } \\
\text { importance }\end{array}$ & \multicolumn{1}{c|}{ Definition } & \multicolumn{1}{c|}{ Explanation } \\
\hline 1 & Equal importance & A is as important as B \\
\hline 3 & Moderate importance & A is a slightly more important than B \\
\hline 5 & Strong importance & A is significately more important than B \\
\hline 7 & Very strong importance & A is strongly more important than B \\
\hline 9 & Extreme importance & A is extremely more important than B \\
\hline $2,4,6,8$ & Medium valors between the previous ones. It is necessary to clarify. \\
\hline
\end{tabular}

Source: Own work based on (Saaty, 1980).

To understand the method, how does it work and why results are truthful, there are some main concepts that should be clear.

\section{Priority:}

After making all the comparisons, the final result is shown in a consensual manner, or the ordering of the alternatives. The result is based mainly on experiences, the issuance of judgments and the evaluation carried out by the participants in the process.

In this level of the hierarchical model it is possible to combine all the judgments, in which an ordering of the alternatives is established from the best to the worst. Moreover, results can be calculated with the arithmetic mean, that shows average values, and geometric mean, that choose the highest value and shows how far from it are the rest of the alternatives.

Inconsistency ratio:

Consistency is defined as the coherence between the particles in a set. In decision making, it can be interpreted as coherence between consecutive decisions or related decisions. For the AHP, consistency is a statistical measure of how close a decision maker is to make logically related or randomly chosen decisions. Saaty proposed the inconsistency 
ratio (CR) to mesure that, from 0 for totally coherent matrixes to 1 for totally random matrixes, and also stated that a matrix can be accepted until CR $\leq 0,1$ (Saaty, 1980).

Sensibility Analysis:

In some problems where a decision must be taken, it is recommended to find the efficient solution instead of the optimal solution.

There is no consensus on how to determine the "quality" of a decision method and reliability of the results obtained. Because of that, sensitivity analysis can be defined as the stability or behavior of the solution to minor modifications preferences occurred during the resolution process or with minor modifications in the values taken for the parameters. Some authors consider that as the efficiency of the multicriteria decision method.

\section{MULTIDIMENSIONAL MODEL DESCRIBING THE STAKEHOLDERS IN A TYPICAL UNIVERSITY}

To form the analysis model, three levels of importance will be taken according to the proximity of the constituents (criteria) and the interest groups that make up each one (subcriteria). The selection of each stakeholder has been done after long research through literature in the field and also because of author's knowledge. The chosen stakeholders are the ones that can affect in some way to universities and their management because of a normal decision.

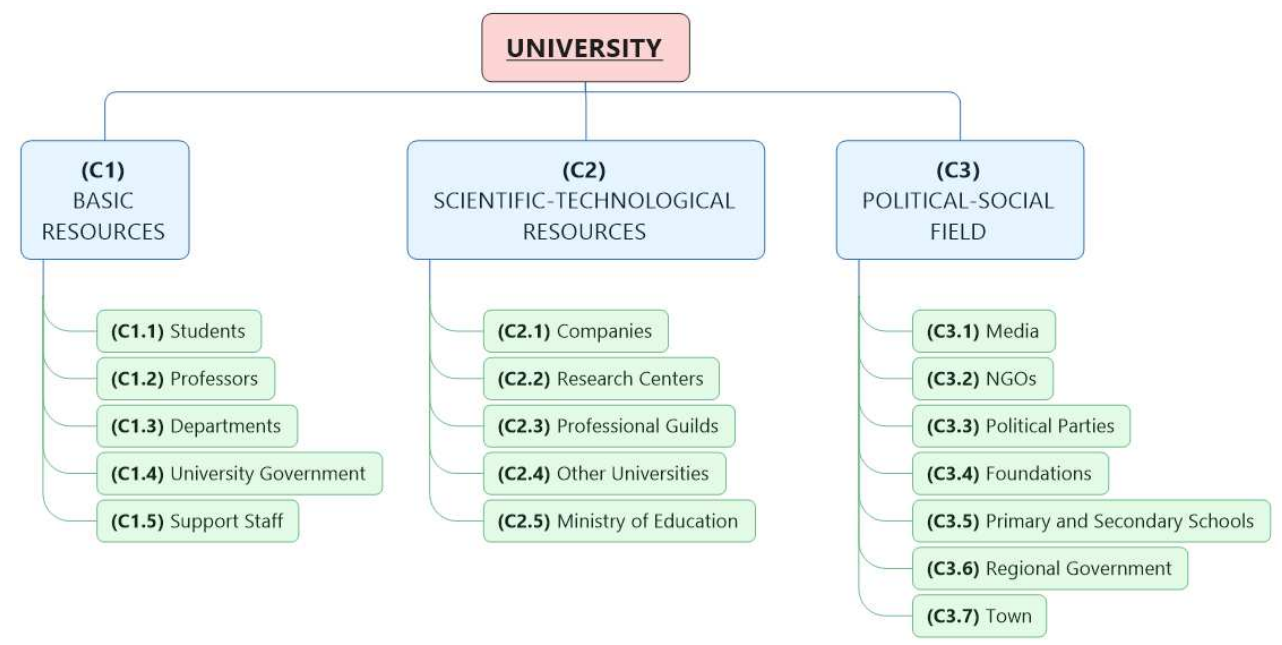

Figure 5. Classification of stakeholders of a university

Source: Own work.

First criterion, (C1) Basic Resources, refers to the closest group of stakeholders to the university, that are those that make it possible for the university to carry out its main mission, which is the creation of knowledge, as well as those that works for its right internal management. These groups are:

- (C1.1.) Students: It is the most numerous group of the first criterion. Its objective is to acquire knowledge and skills to be able to play a role in their future work. 
- (C1.2.) Professors: This group has the first function of transmitting knowledge to students. In addition, they must be up to date with the most efficient teaching techniques and be able to apply them.

- (C1.3) Departments: This group is responsible for managing the resources of the first criterion, whether human resources, material, economic, etc.

- (C1.4.) University Government: It is the maximum group of government and its attributions are to modify the statute and decide on the creation, modification or suppression of academic units, colleges and school.

- (C1.5.) Support Staff: This group performs temporary support work to the previous sub-criteria.

Second criterion, (C2) Scientific-Technological Context, refers to the group of stakeholders who, with a similar or different purpose from that of the university, can benefit from the groups of the first level. These groups are:

- (C2.1.) Companies: These groups generally have their own mission different from that of the university. However, they can benefit from the knowledge generated in the university through future employees or collaborations.

- (C2.2.) Research Centers: These groups are responsible for research, development and possible implementation of new knowledge. Like companies, they can benefit from the knowledge generated in the university.

- (C2.3.) Professional Guilds: These groups are formed by people with the same studies after passing through the university. His interest is based on guaranteeing decent conditions for the proper performance of each profession.

- (C2.4.) Other Universities: These groups are formed by all universities and their objective is to be competent with respect to others in quality teaching, support and services.

- (C2.5.) Ministry of Education: These are official groups responsible for managing administrative tasks related to education and usually also for culture.

Finally, third criterion, (C3) Political-Social Field, refers to the group of stakeholders that have a totally different mission from the university, but somehow, they are related to it, either by proximity, by land use, by influence, etc. These groups are:

- (C3.1.) Media: These groups are responsible for disseminating the information. This can be related to university events and can also benefit from future employees.

- (C3.2.) NGOs: These groups are normally made up of normal people. They can have great influence on social issues, therefore, they can condition decisions about university management.

- (C3.3.) Political Parties: These groups aim to govern the country. Depending on the winning party, the way to govern is different, and this directly affects the curricula of the universities.

- (C3.4.) Foundations: These groups can be made up of companies or NGOs and their goal is to scholarship students either by necessity or by their academic record.

- (C3.5.) Primary and Secondary Schools: These groups are made up of centers where students acquire their knowledge before going to university. Therefore, the contents and teaching methods must be related to those taught at the university.

- (C3.6.) Regional Government: This groups govern the city where the university is located and can make unilateral decisions about its facilities or knowledge to be imparted, as well as influence its financing. 
- (C3.7.) Towns: These groups have as interest the contribution of added value to their territory, the increase in population and university-related advantages. They can influence the infrastructure reforms of the university. This is a stakeholders list that can be found in the most of the universities. As it is easy to see in the next table, there are many things to have in mind at the time that a decision is taken. Moreover, it is impossible to satisfy every stakeholder. That is why it is very important to analyze properly the details of each decision and estimate its repercussions.

The process of taking a decision always is motivated by interests and looks for a purpose. Troubles appears when these purposes or interests are the opposite of the ones of some stakeholders. In this case, each part has to try to negotiate and reach an agreement. Otherwise, the relationship or collaboration that exists between the parts can break.

After describing each stakeholder, next table shows the purpose of this one and what do they get from university. It is important to make it clear for helping experts understand what are they choosing for. And, because of that, results will be more truthful.

Table 3. Purposes and interests on university of Stakeholders

\begin{tabular}{|l|l|l|l|}
\hline No. & \multicolumn{1}{|c|}{ DESCRIPTION } & \multicolumn{1}{|c|}{ PURPOSE } & \multicolumn{1}{|c|}{$\begin{array}{c}\text { INTEREST ON } \\
\text { UNIVERTITY }\end{array}$} \\
\hline- & UNIVERSITY & $\begin{array}{l}\text { Creation of knowledge. } \\
\text { Offer of quality services. }\end{array}$ & $\begin{array}{l}\text { Get prestige, collaborations } \\
\text { and finnancing. }\end{array}$ \\
\hline C1 & $\begin{array}{l}\text { BASIC } \\
\text { RESOURCES }\end{array}$ & $\begin{array}{l}\text { Make the university achieve its } \\
\text { purpose. }\end{array}$ & $\begin{array}{l}\text { Good working of the } \\
\text { university management. }\end{array}$ \\
\hline C1.1 & Students & $\begin{array}{l}\text { Acquire new knowledge. } \\
\text { Acquire transversal competences. }\end{array}$ & $\begin{array}{l}\text { Being prepared for the } \\
\text { future job. }\end{array}$ \\
\hline C1.2 & Professors & $\begin{array}{l}\text { Provide knowledge to the students. } \\
\text { Apply teaching techniques. } \\
\text { Get money. }\end{array}$ & $\begin{array}{l}\text { Create new knowledge. } \\
\text { Make the university } \\
\text { manage system work. }\end{array}$ \\
\hline C1.3 & Departments & Manage resources of the univerity. & $\begin{array}{l}\text { Good management in } \\
\text { university sub-levels. }\end{array}$ \\
\hline C1.4 & $\begin{array}{l}\text { University } \\
\text { Government }\end{array}$ & $\begin{array}{l}\text { Decide, create and modify } \\
\text { academic plan. }\end{array}$ & $\begin{array}{l}\text { Make a competent } \\
\text { university. }\end{array}$ \\
\hline C1.5 & Support Staff & $\begin{array}{l}\text { Support University employees. } \\
\text { Get money. }\end{array}$ & $\begin{array}{l}\text { Make the university } \\
\text { manage system work. }\end{array}$ \\
\hline C2 & $\begin{array}{l}\text { SCIENTIFIC- } \\
\text { POLITICAL } \\
\text { CONTEXT }\end{array}$ & $\begin{array}{l}\text { Develop products. } \\
\text { Offer services and get money. }\end{array}$ & $\begin{array}{l}\text { Benefits about knowledge } \\
\text { created. } \\
\text { Make collaborations. }\end{array}$ \\
\hline C2.1 & Companies & Offer services and get money. & $\begin{array}{l}\text { Benefits about students as } \\
\text { future employees. }\end{array}$ \\
\hline C2.2 & Research Centers & $\begin{array}{l}\text { Create knowledge. } \\
\text { Offer services and get money. }\end{array}$ & $\begin{array}{l}\text { Benefits about students as } \\
\text { future researchers. }\end{array}$ \\
\hline C2.3 & Professional Guilds & $\begin{array}{l}\text { Guarantee quality conditions for } \\
\text { a proper performance of the job. }\end{array}$ & $\begin{array}{l}\text { Benefits about students as } \\
\text { future members. }\end{array}$ \\
\hline C2.4 & Other Universities & $\begin{array}{l}\text { Creation of knowledge. } \\
\text { Offer of quality services. } \\
\text { Be competent with other } \\
\text { universities. }\end{array}$ & $\begin{array}{l}\text { Get prestige, collaborations } \\
\text { and finnancing. }\end{array}$ \\
tasks. & Ministry of Education & $\begin{array}{l}\text { Manage education administrative } \\
\text { Good working of education }\end{array}$ & $\begin{array}{l}\text { Goonstem. } \\
\text { system }\end{array}$ \\
\hline
\end{tabular}


Table 3 (cont.). Purposes and interests on university of Stakeholders

\begin{tabular}{|l|l|l|l|}
\hline No. & \multicolumn{1}{|c|}{ DESCRIPTION } & \multicolumn{1}{|c|}{ PURPOSE } & \multicolumn{1}{|c|}{$\begin{array}{c}\text { INTEREST ON } \\
\text { UNIVERTITY }\end{array}$} \\
\hline C3 & $\begin{array}{l}\text { POLITICAL- } \\
\text { SOCIAL FIELD }\end{array}$ & Different purposes. & $\begin{array}{l}\text { Influence on decisions of the } \\
\text { university. }\end{array}$ \\
\hline C3.1 & Media & Provide information. & $\begin{array}{l}\text { Provide information about new } \\
\text { knowledge. }\end{array}$ \\
\hline C3.2 & NGOs & Help on social issues. & $\begin{array}{l}\text { Check about universities social } \\
\text { policy. }\end{array}$ \\
\hline C3.3 & Political Parties & Govern the country. & $\begin{array}{l}\text { Change academic plan. } \\
\text { Manage the financing. }\end{array}$ \\
\hline C3.4 & Foundations & Give scholarships. & $\begin{array}{l}\text { Benefits of the knowledge of } \\
\text { the best students. }\end{array}$ \\
\hline C3.5 & $\begin{array}{l}\text { Primary and } \\
\text { Secondary Schools }\end{array}$ & Creation of knowledge. & $\begin{array}{l}\text { Get prestige, collaborations } \\
\text { and finnancing. }\end{array}$ \\
\hline C3.6 & $\begin{array}{l}\text { Regional } \\
\text { Governments }\end{array}$ & Govern provinces. & $\begin{array}{l}\text { Change academic plan. } \\
\text { Influence on infrastructures. }\end{array}$ \\
\hline C3.7 & Towns & Live in harmony. & Influence on infrastructures. \\
\hline
\end{tabular}

Source: Own work.

\section{ASSESSMENT OF THE SIGNIFICANCE OF EFFICIENT STAKEHOLDERS MANAGEMENT}

After receiving the questionnaires from experts (Annexe 1) and write the information in the software, the priorities of each expert have been calculated. Then, the geometric mean of each priority has been found (Annexe 2) and they have been written again in the software to get the final priorities (Annexe 2). Next tables show priorities for criteria and subcriteria, organized from higher to lower.

First, according to criteria priorities, it is clear that (C1) Basic resources is considerably more important than (C2) Scientific-technological resources, and it is also much more important than (C3) Political-social field.

Table 4. Priorities of criteria

\begin{tabular}{|l|c|}
\hline \multicolumn{1}{|c|}{ CRITERIA } & PRIORITIES \\
\hline C1-BASIC RESOURCES & 0,4929 \\
\hline C2-SCIENTIFIC-TECHNOLOGICAL RESOURCES & 0,3748 \\
\hline C3-POLITICAL-SOCIAL FIELD & 0,1323 \\
\hline \multicolumn{2}{r}{ TOTAL } \\
\hline
\end{tabular}

Source: Own work.

Otherwise, according to subcriteria priorities, first (C1.1) Students and then (C1.2) Professors are clearly more important than the rest. In the other hand, importance of (C3.3) Political parties is minimum. 
Table 5. Priorities of subcriteria

\begin{tabular}{|l|c|}
\hline \multicolumn{1}{|c|}{ SUBCRITERIA } & PRIORITIES \\
\hline C1.1-STUDENTS & 0,1977 \\
\hline C1.2-PROFESSORS & 0,1601 \\
\hline C2.5-MINISTRY OF EDUCATION & 0,1054 \\
\hline C2.1-COMPANIES & 0,1024 \\
\hline C2.2-RESEARCH CENTERS & 0,0803 \\
\hline C1.3-DEPARTMENTS & 0,0546 \\
\hline C2.4-OTHER UNIVERSITIES & 0,0524 \\
\hline C1.4-UNIVERSITY GOVERNMENT & 0,0520 \\
\hline C3.6-REGIONAL GOVERNMENT & 0,0394 \\
\hline C2.3-PROFESSIONAL GUILDS & 0,0344 \\
\hline C1.5-SUPPORT STAFF & 0,0285 \\
\hline C3.7-TOWN & 0,0278 \\
\hline C3.1-MEDIA & 0,0159 \\
\hline C3.5-PRIMARY AND SECONDARY SCHOOLS & 0,0154 \\
\hline C3.4-FOUNDATIONS & 0,0133 \\
\hline C3.2-NGOs & 0,0109 \\
\hline C3.3-POLITICAL PARTIES & 0,0095 \\
\hline & $\mathbf{1 , 0 0 0 0}$ \\
\hline
\end{tabular}

Source: Own work.

This result shows that in a normal situation, if a decision for the university affects to all these stakeholders, it should be taken thinking, first of all, about students and professors, looking for as best consequences as possible for them. Also, if the decision affects stakeholders negatively, the less bad consequences should be for students and professors.

\section{CONCLUSION AND FUTURE RESEARCH}

Analytic Hierarchy Process is a useful tool to help making decisions in different situations. Very often, decisions that are crucial for future developments must be taken. In addition, decision makers assume huge responsibilities and, in many times, they have to rely on experts to advise them. And also, sometimes there are different agents with conflicting interests that must be combined to reach a solution.

In this paper, AHP has been used to help decision makers when they have to manage the stakeholders of a university and they have to decide about any topic that can affect to those stakeholders. Moreover, data used for getting the results has been given by some experts in the field. And according to the results, in a normal situation, decisions should benefit students before the rest of the stakeholders.

These results make sense because without students and professors, universities cannot carry out their main objective as creators of knowledge. Moreover, according to results, students and professor are notably more important than the rest, so achieve a good relation between them could be synonymous with success. As Spilt, Koomen, \& Thijs, (2011) states, "According to theoretical models of relationships, teachers' emotional involvement with 
students in the classroom is driven by a basic psychological need for relatedness or communion".

Nowadays, it is impossible to imagine a university with the only objective of knowledge creators. All of them have many symbiotic relationships with a lot of stakeholders, from where all of them receive some benefits from each other. In this research, it can be found the priorities that should be considered.

In any situation that a decision maker has to deal with many stakeholders, the processes of identify them and their interests, plan their management and manage and control their participation can be the difference between fail and success, and of course, avoid future problems.

Otherwise, this research also can help not only in taking decisions related to universities but with their future development. In this paper, university's management model has been described as a model close to public governance, whose objectives are focussed on the consolidation of the rule of law, the strengthening of democracy and the recognition of the position of citizens in their relationship with the public administration. So, the fact that the students should be the highest priority makes sense if a university wants to follow this open government model.

There are many thigs to write about in this field. Next research should light up ways to reach management models closer to public governance and methods to strengthen relationships between students and professors.

\section{REFERENCES}

Ackermann, F., Eden, C. (2011). Strategic Management of Stakeholders: Theory and Practice. "Long Range Planning", Vol. 44 (3).

Aragonés, P., García, M., Montesinos, J. (2017). How to assess stakeholders' influence in project management? A proposal based on the Analytic Network Process. "International journal of project management", Vol. 35 (3).

Bryson, J. (2007). What to do when Stakeholders matter. Stakeholder Identification and Analysis Techniques. "Public Management Review", Vol. 6 (1).

Bryson, J., Cunningham, G., Lokkesmoe, K. (2002). What to do when stakeholders matter: The case of problem formulation for the African American men project of Hennepin County, Minnesota. "Public Administration Review", Vol. 62.

Builes, L., Lotero, L. (2012). Análisis y variabilidad de la consistencia en un proceso jerárquico de toma de decisiones ambientales.

Caballero, G., Váxquez, X., Quintás, M. (2009). ¿Que influencia tienen los stakeholders de la universidad española en la empleabilidad de sus alumnos? Propuestas de reforma. "Cuadernos de Economía y Dirección de la Empresa", Vol. 12 (38).

Duque, E. (2009). La gestión de la universidad como elemento básico del sistema universitario: una reflexión desde la perspectiva de los stakeholders. "Innovar".

Dwevedi, P. (2017). Simplilearn. Access on the internet: https://www.simplilearn.com/how-tocontrol-stakeholder-management-effectively-article

Freeman, E., McVea, J. (1983). A Stakeholder Approach to Strategic Management. Virginia.

Freeman, E., Reed, D. (1983). Stockholders and Stakehorlders; A New Perspective on Corporate Governance. "California Management Review", Vol. 25. 
Gaete, R. (2011). Compartiendo Experiencias Universitarias. Access on the internet: http://compartiendoexperienciauniversitaria.blogspot.com/2011/11/quienes-son-losstakeholders-de-una.html

Gaete, R. (2011). Relación de las universidades con sus stakeholders en Internet: un modelo de análisis. "Ciencia, Docencia y Tecnología", Vol. 22 (42).

Giner, G., Aragonés, P., Niclós, J. (2012). The application of the analytic network process to the assessment of best available techniques. "Journal of cleaner production", Vol. 25, 86-95.

Katsamunska, P. (2016). The Concept of Governance and Public Governance Theories. "Economic Alternatives", Issue 2.

Meléndez, M.Á., Solís, P., Romero, J.I. (2010). Gobernanza y gestión de la universidad Pública. "Revista de Ciencias Sociales".

Mitchell, R., Agle, B., Wood, D. (1997). Toward a Theory of Stakeholder Identification and Salience: Defining the Principle of Who and Really Counts. "The Academy of Management Review", Vol. 22 (4).

NArváez, J. (2008). La universidad y su gestión. "Gestión universitaria", Vol. 1 (1).

Naser, A., Ramírez-Alujas, Á., Rosales, D. (2017). Desde el gobierno abierto al Estado abierto en América Latina y el Caribe. Santiago.

Oszlak, O. (2015). Gobierno abierto: promesas, supuestos, desafíos. Jornada sobre gobierno abierto y prevención de la tortura.

Pérez, A. (2015). Ceolevel. Access on the internet: http://www.ceolevel.com/que-hay-detras-dela-expresion-gestion-de-los-stakeholders

Prost, J., Preston, L., Sachs, S. (2002). Managing the Extended Enterprise: The New Stakeholder View. "California Management Review", Vol. 45 (1).

Prusak, A., Strojny, J., Stefanow, P. (2014). Analityczny Proces Hierarchiczny (AHP) na skróty - kluczowe pojęcia i literatura. "Humanities and Social Sciences", Vol. 4 (19.21).

Saaty, T. (1980). The Analytic Hierarchical Process. New York.

Spilt, J.L., Koomen, H.M., Thijs, J.T. (2011). Teacher Wellbeing: The Importance of TeacherStudent Relationships. "Educ Psychol Rev", Vol. 23.

Strojny, J. (2015). Implementation of the AHP and benchmarking in Strategic Analysis of Polish Regions. "Procedia-Social and Behavioral Sciences", Vol. 213.

Strojny, J., Baran, M. (2013). Kompleksowe podejście do zarządzania projektami na przykładzie uczelni wyższej. "Przedsiębiorczość i Zarzqdzanie". Wydawnictwo SAN, Vol. 14 (12).

Valle, M. (2005). Modelo de gestión universitaria basado en indicadores por dimensiones relevantes. Revista Iberoamericana de Educación.

Vidal, F. (2017). Nueva Revista. Access on the internet: https://www.nuevarevista.net/ universidad/nuevos-modelos-gobernanza-las-universidades-publicas/

Villoria, M. (2012). El gobierno abierto como subsistema de políticas: una evaluación desde el institucionalismo discursivo. "La promesa del gobierno abierto".

Vries, W.D., Ibarra, E. (2004). La gestión de la unviersidad, interrogantes y problemas en busca de respuestas. RMIE, Vol. 9 (22).

Wagner, E., Alves, H., Raposo, M. (2010). An Exploratory Research on the Stakeholders of a University. "Journal of Management and Strategy", Vol. 1 (1). 


\section{ANNEX}

Priorities results got from the software SuperDecisions and Microsoft Excel. PDF file (AHP Results)

1.- Structure of criteria and subcriteria: in the software SuperDecisions.

(2) Super Decisions Main Window: Annexe 3. AHP Analysis.sdmod

File Design Assess/Compare Computations Networks Help

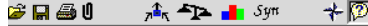

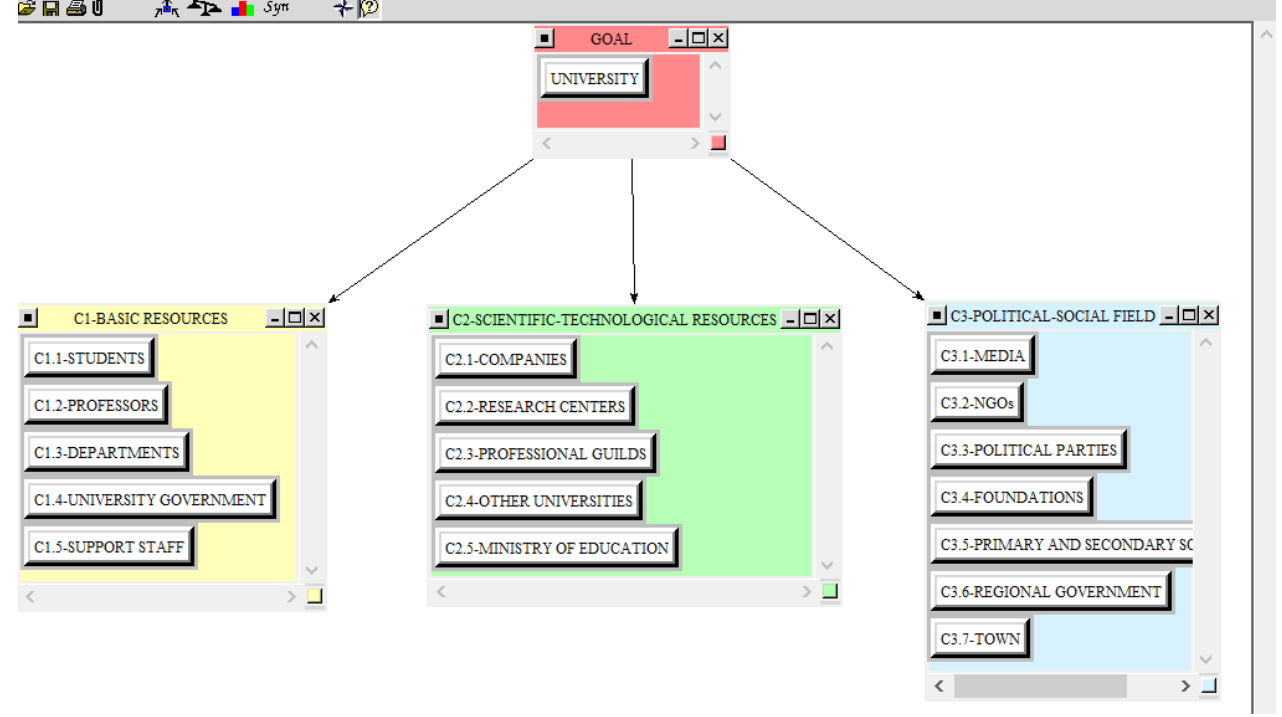

2.- Calculations of geometric mean of experts decisions: with the software Microsfot Excel.

\begin{tabular}{|l|c|}
\hline \multicolumn{1}{|c|}{ CRITERIA } & GEOM. MEAN \\
\hline C1-BASIC RESOURCES & 0,4568 \\
\hline C2-SCIENTIFIC-TECHNOLOGICAL RESOURCES & 0,3474 \\
\hline C3-POLITICAL-SOCIAL FIELD & 0,1226 \\
\hline
\end{tabular}




\begin{tabular}{|l|c|}
\hline \multicolumn{1}{|c|}{ SUBCRITERIA } & GEOM. MEAN \\
\hline C1.1-STUDENTS & 0,1806 \\
\hline C1.2-PROFESSORS & 0,1463 \\
\hline C1.3-DEPARTMENTS & 0,0499 \\
\hline C1.4-UNIVERSITY GOVERNMENT & 0,0475 \\
\hline C1.5-SUPPORT STAFF & 0,0260 \\
\hline C2.1-COMPANIES & 0,0872 \\
\hline C2.2-RESEARCH CENTERS & 0,0684 \\
\hline C2.3-PROFESSIONAL GUILDS & 0,0293 \\
\hline C2.4-OTHER UNIVERSITIES & 0,0446 \\
\hline C2.5-MINISTRY OF EDUCATION & 0,0898 \\
\hline C3.1-MEDIA & 0,0134 \\
\hline C3.2-NGOS & 0,0092 \\
\hline C3.3-POLITICAL PARTIES & 0,0080 \\
\hline C3.4-FOUNDATIONS & 0,0112 \\
\hline C3.5-PRIMARY AND SECONDARY SCHOOLS & 0,0130 \\
\hline C3.6-REGIONAL GOVERNMENT & 0,0332 \\
\hline C3.7-TOWN & 0,0234 \\
\hline
\end{tabular}

3.- Priorities of criteria: calculated with software SuperDecisions.

\begin{tabular}{|c|c|c|c|c|}
\hline \multicolumn{3}{|c|}{ (2) Super Decisions Main Window: Annexe 3. AHP Analysis.sdmod: Cluster Matrix View } & - & \multirow{2}{*}{$\begin{array}{c}\times \\
\text { GOAL }\end{array}$} \\
\hline $\begin{array}{l}\text { Cluster } \\
\text { Node Labels }\end{array}$ & C1-BASIC RESOURCES & C2-SCIENTIFIC-TECHNOLOGICAL RESOURCES & C3-POLITICAL-SOCIAL FIELD & \\
\hline $\begin{array}{l}\text { C1-BASIC } \\
\text { RESOURCE } \\
\mathrm{S}\end{array}$ & 0.000000 & 0.000000 & 0.000000 & 0.493616 \\
\hline $\begin{array}{l}\text { C2-SCIENTIFIC- } \\
\text { TECHNOLOGIC } \\
\text { AL RESOURCES }\end{array}$ & 0.000000 & 0.000000 & 0.000000 & 0.374485 \\
\hline $\begin{array}{l}\text { C3-POLITICA } \\
\text { L-SOCIAL } \\
\text { FIELD }\end{array}$ & 0.000000 & 0.000000 & 0.000000 & 0.131899 \\
\hline $\begin{array}{l}\text { GOA } \\
\mathrm{L}\end{array}$ & 0.000000 & 0.000000 & 0.000000 & 0.000000 \\
\hline
\end{tabular}


Stakeholders management in a university ...

4.- Priorities of subcriteria: calculated with the software SuperDecisions.

Super Decisions Main Window: Annexe 3. AHP Analysis.sdmo... $\quad-\quad \square \quad$ ×

\begin{tabular}{|c|c|c|c|}
\hline \multicolumn{4}{|c|}{ Here are the priorities. } \\
\hline Icon & Name & $\longdiv { \text { Normalized by Cluster } }$ & Limiting \\
\hline No Icon & C1.1-STUDENTS & 0.39189 & 0.193444 \\
\hline No Icon & C1.2-PROFESSORS & 0.32816 & 0.161986 \\
\hline No Icon & C1.3-DEPARTMENTS & 0.11104 & 0.054810 \\
\hline No Icon & $\begin{array}{l}\text { C1.4-UNIVERSITY } \\
\text { GOVERNMENT }\end{array}$ & 0.11058 & 0.054582 \\
\hline No Icon & C1.5-SUPPORT STAFF & 0.05833 & 0.028794 \\
\hline No Icon & C2.1-COMPANIES & 0.27723 & 0.103819 \\
\hline No Icon & C2.2-RESEARCH CENTERS & 0.21005 & 0.078662 \\
\hline No Icon & C2.3-PROFESSIONAL GUILDS & 0.09248 & 0.034634 \\
\hline No Icon & C2.4-OTHER UNIVERSITIES & 0.13890 & 0.052015 \\
\hline No Icon & $\begin{array}{l}\text { C2.5-MINISTRY OF } \\
\text { EDUCATION }\end{array}$ & 0.28133 & 0.105355 \\
\hline No Icon & C3.1-MEDIA & 0.12031 & 0.015869 \\
\hline No Icon & $\mathrm{C} 3.2-\mathrm{NGOs}$ & 0.08376 & 0.011048 \\
\hline No Icon & C3.3-POLITICAL PARTIES & 0.07312 & 0.009645 \\
\hline No Icon & C3.4-FOUNDATIONS & 0.10473 & 0.013814 \\
\hline No Icon & $\begin{array}{r}\text { C3.5-PRIMARY AND } \\
\text { SECONDARY SCHOOLS }\end{array}$ & 0.11715 & 0.015452 \\
\hline No Icon & C3.6-REGIONAL GOVERNMENT & 0.29551 & 0.038977 \\
\hline No Icon & C3.7-TOWN & 0.20541 & 0.027093 \\
\hline No Icon & UNIVERSITY & 0.00000 & 0.000000 \\
\hline
\end{tabular}

DOI: 10.7862/rz.2020.mmr.12

The text was submitted to the editorial office: February 2020.

The text was accepted for publication: June 2020. 
